\title{
Effect of fermented sorghum seed meal on the performance, carcass characteristics and blood profile of broiler finisher chicken
}

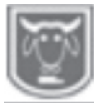

\author{
Esiegwu, A. C.
}

Department of Animal Science and Fisheries, Imo State University, PMB 2000 Owerri, Nigeria.

Abstract Corresponding author: arthuresiegwu@yahoo.com; +2348032457629.

Sorghum is a good and promising energy source that can replace maize in poultry ration. Thus, an experiment was conducted to investigate the effect of fermented sorghum seed meal (FSSM) on performance, carcass characteristics and blood indices of broiler finisher birds. Fermented sorghum seed meal (FSSM) was used to formulate four broiler finisher rations at $0 \%, 10 \%, 20 \%$ and 30\% inclusion levels. Four groups of fifteen broiler chicks of Agrited breed were randomly assigned to four treatment diets in a completely randomized design and fed for 28 days. Each group was further subdivided into three replicates offive birds each. The average daily weight gain, average daily feed intake and feed conversion ratio did not show any significant difference ( $p>0.05)$. The feed cost per $\mathrm{kg}$ weight gain decreased as the fermented sorghum seed meal increased. All the carcass parameters measured (\% dressed weight, \% thigh, \% breast muscle, \% wing) and the internal organ weights (heart\%live weight $(L W)$, gizzard $\% L W$ and liver $\% L W)$ were not significantly different $(p>0.05)$. The haemoglobin (HB), packed cell volume (PCV) and red blood cell (RBC) increased significantly $(p<0.05)$ as the FSSM increased. The white blood cell $(W B C)$, mean cell volume $(\mathrm{MCV})$, mean cell haemoglobin (MCH), neutrophiles, basophiles, eosinophiles, lymphocytes and monocytes did not show any treatment effect $(p>0.05)$. The biochemical indices revealed that urea and cholesterol increased significantly $(p<0.05)$ at $20 \%$ and $30 \%$ inclusion levels of FSSM. Creatinine, total proteins, albumin, globulin and the electrolytes ( $\mathrm{Na}, \mathrm{K}, \mathrm{Co}_{3}$ and $\mathrm{CL}$ ) did not show any significant treatment $(p>0.05)$ effect. The enzymes serum glutamate oxaloacetate transaminase (SGOT) and serum glutamate pyruvate transaminase (SGPT) increased significantly $(p>0.05)$ at $20 \%$ and $30 \%$ inclusion levels of FSSM. It was therefore concluded that fermented sorghum seed meal could be incorporated into broiler finisher ration up to $30 \%$ level due to cost effectiveness at this level.

Keywords: Fermented, Sorghum seed meal, performance, carcass, blood indices

\section{Introduction}

It is obvious that maize is the key energy source for poultry. It is a widely utilised cereal grain by man that is processed into various food items such as pap, popcorn, ikpaoka (that is, maize grain that is ground, cooked, and allowed to coagulate for eating). It is also utilised by the livestock industry to produce animal feeds and industrially to produce wheat flour, corn bread and other baked products. This high value placed on maize has mounted so much pressure on its demand that too many people are chasing the few tons available in the market leading to increase in price. Essentially, the high rate of inflation in Nigeria coupled with the sudden outburst of stem borer attack on maize production since 2016 in Nigeria that devastated hectares of maize plot aggravated the scarcity of maize grains. It is therefore necessary to research into possible alternative feed energy sources that can take the place of maize by either partially or wholly replacing maize in broiler feed ration to ensure the sustainability of the poultry industry.

Sorghum is a good and promising energy source that can replace maize in poultry 


\section{Effect of fermented sorghum seed meal on broiler finisher chicken}

ration. It has been reported that sorghum grain is a suitable substitute for maize in poultry diets (Dowling et al., 2002). Sorghum contains about $14.89 \%$ crude protein, $3.30 \%$ ether extract, $3.01 \%$ crude fibre, $2.59 \%$ ash and $65.16 \%$ nitrogen free extract (Etuk and Ukaejiofo, 2007). However, sorghum contains up to $6 \%$ tannin (Doka et al., 2004; Dicko et al., 2005). Tannin has an astringent taste that impacts negatively on feed intake, palatability and digestibility (Kim and Miller, 2005) with a resultant decrease in weight gain. The limiting factor in sorghum usage as energy source for poultry is the presence of tannin. The need to process the seeds to reduce this anti-nutrient becomes very necessary. Water treatment has been used successfully to reduce the tannin level in sorghum grain (Sherif et al., 2012) and used as replacement for maize in broiler diet. This study therefore, was aimed at evaluating the response of broiler chickens fed fermented sorghum seed meal.

\section{Materials and methods}

\section{Experimental site}

This experiment was carried out at the Poultry unit of Teaching and Research farm, Imo State University, Owerri, which is located within the South-Eastern agroecological zone of Nigeria. Owerri lies between latitude $5^{\circ} 29^{\prime} \mathrm{N}$ and longitude $7^{\circ} 20^{\prime} \mathrm{E}$. It is about $91 \mathrm{~m}$ above sea level with annual rainfall, temperature and humidity ranging from $1,500 \mathrm{~mm}$ to $2,200 \mathrm{~mm}$, $20.0-27.5^{\circ} \mathrm{C}$ and $75-90 \%$, respectively (Accuweather, 2015).

Source and processing of fermented sorghum seed meal

The sorghum seeds and other feed materials were procured at Ekeonuwa Market and Fidelity Feed Mill in Owerri, Imo State. The sorghum seeds were soaked in water for three days. It was then dried under the sun for five days. Thereafter, it was ground in a hammer mill into a powdery sorghum seed meal known as fermented sorghum seed meal (FSSM). A sample of FSSM was then sent to the laboratory for proximate analysis. The analysis was carried out according to the method of AOAC (2010). The metabolisable energy (ME) was calculated according to the method of Pauzenga (1985).

$\mathrm{ME}=(37 \mathrm{X}$ crude protein $)+(81.8 \mathrm{X}$ ether extract $)+(35.5 \mathrm{X}$ nitrogen free extract $)$

\section{Experimental diets}

Fermented sorghum seed meal was used to formulate four broiler finisher diets $(20 \%$ $\mathrm{CP}$ ) at inclusion levels of $0 \%, 10 \%, 20 \%$ and $30 \%$, respectively. The ingredient and the calculated nutrient composition of the experimental diets are shown in Table 1.

\section{Experimental birds and design}

Sixty one-day old Marshal broiler chicks were purchased from a certified poultry vendor in Owerri. The chicks were brooded for four weeks and fed commercial feed. Thereafter, the birds were divided into four groups of 15 each in a completely randomized design. Each group was further subdivided into three replicates of five birds per replicate. Each of the groups was assigned to one of the four treatment diets. The initial live weight of the birds was taken using a weighing scale and recorded. Thereafter, the weight of the birds was taken on weekly basis. The birds were fed ad libitum. Clean fresh drinking water was supplied to the birds regularly. Feeding trial lasted for four weeks.

\section{Data collection}

Feed intake was recorded daily and the birds weighed weekly after taking the initial body weight. Feed intake was determined by weighing the feed offered and the left-over the following day. The difference between the two values was the feed consumed. Feed conversion ratio was determined by dividing average daily feed intake by average daily 


\section{Esiegwu}

Table 1: Ingredient and calculated nutrient composition of the experimental diet

\begin{tabular}{lrrrr}
\hline & \multicolumn{3}{c}{ Dietary levels (\%) DM) } & \\
\cline { 2 - 5 } Ingredient & $\mathbf{T}_{\mathbf{1}}(\mathbf{0 . 0 0} \%)$ & $\mathbf{T}_{\mathbf{2}} \mathbf{( 1 0 . 0 0 \% )}$ & $\mathbf{T}_{\mathbf{3}} \mathbf{( 2 0 . 0 0 \% )}$ & $\mathbf{T}_{\mathbf{4}} \mathbf{( 3 0 . 0 0 \% )}$ \\
\hline Maize & 60.00 & 50.00 & 40.00 & 30.00 \\
Sorghum & 0.00 & 10.00 & 20.00 & 30.00 \\
Soyabean & 14.00 & 14.00 & 14.00 & 14.00 \\
GNC & 10.00 & 10.00 & 10.00 & 10.00 \\
Fish & 2.00 & 2.00 & 2.00 & 2.00 \\
Blend meal & 2.00 & 2.00 & 2.00 & 2.00 \\
PKC & 3.00 & 3.00 & 3.00 & 3.00 \\
Wheat meal & 4.00 & 4.0 & 4.00 & 4.00 \\
Bone meal & 4.00 & 4.00 & 4.00 & 4.00 \\
Vit. Premix & 0.25 & 0.25 & 0.25 & 0.25 \\
Salt & 0.25 & 0.25 & 0.25 & 0.25 \\
Lysine & 0.25 & 0.25 & 0.25 & 0.25 \\
Methionine & 0.25 & 0.25 & 0.25 & 0.25 \\
Total & 100.00 & 100.00 & 100.00 & 100.00 \\
Calculated nutrient composition & & & \\
Crude protein & 20.03 & 20.50 & 20.98 & 21.45 \\
Crude fibre & 3.80 & 3.66 & 3.50 & 3.37 \\
Ether extract & 4.40 & 4.15 & 3.89 & 3.69 \\
Ash & 2.98 & 2.97 & 2.97 & 2.96 \\
Calcium & 1.58 & 1.58 & 1.58 & 1.58 \\
Phosphorous & 1.10 & 1.07 & 1.04 & 1.01 \\
Lysine & 1.20 & 1.42 & 1.40 & 1.37 \\
Methionine & 0.59 & 0.82 & 0.20 & 0.78 \\
ME (Kcal/kg) & 2911.22 & 2898.94 & 2886.66 & 2874.38 \\
\hline
\end{tabular}

body weight gain.

\section{Haematological studies}

Blood samples were collected from three birds per treatment at the end of the experiment from the wing web of the birds using syringe and needle and placed in the specimen bottles with EDTA (Ethylene Diamine Tetra Acetate) for haematological studies. Blood was analyzed within three hours of collection for haemoglobin $(\mathrm{Hb})$ level, white blood cells (WBC), red blood cells $(\mathrm{RBC})$, packed cell volume (PCV), mean corpuscular volume (MCV), mean corpuscular haemoglobin $(\mathrm{MCH})$, mean corpuscular haemoglobin concenteration (MCHC), neutrophils, basophils, eosinophil, lymphocytes and monocytes using standard methods (Monica, 1984).

Serum biochemistry

Blood samples collected were placed in the specimen bottles without EDTA for biochemical studies. Serum biochemical indices analysed were total protein, urea, creatinine, cholesterol, sodium, potassium, chloride, carbonate and serum enzymes as outlined by Ochie and Kolhatkar (2000).

\section{Carcass evaluation}

At the end of the feeding trial, three birds were randomly selected from each treatment for carcass evaluation. These birds were starved overnight to empty their intestines to avoid faecal contamination during carcass processing but were supplied with water. The birds were weighed, slaughtered, defeathered and eviscerated. The live weights and dressed weights were recorded. The dressed weights were determined by removing the viscera (alimentary canal and the internal organs) through a slit cut on the posterior end of the abdominal region. The 


\section{Effect of fermented sorghum seed meal on broiler finisher chicken}

neck, drumstick, breast muscle, back, wing and internal organs (heart, liver and gizzard) were weighed and calculated as a percentage of the live weights $(\% \mathrm{LW})$. The length of the intestine was measured with the aid of a measuring tape.

\section{Cost analysis}

Efficiency of production was determined as follows:-

Cost of feed $(\mathrm{N} / \mathrm{kg})=\mathrm{a}$

$\mathrm{Kg}$ feed $/ \mathrm{kg}$ weight gain $=\mathrm{b}$

Cost of feed $/ \mathrm{kg}$ weight gain $=\mathrm{a} \times \mathrm{b}$

\section{Statistical analysis}

Data obtained on each parameter measured was subjected to one way analsis of variance (ANOVA) (Snedecor and Cochran, 1987). The difference between the treatment means were compared using Duncan's new multiple range test (DNMRT) as outlined by obi (1990).

\section{Results and discussion}

\section{Proximate composition of sorghum seed meal}

The proximate composition of sorghum seed meal used for the experiment is shown in Table 2. The sorghum contained about
$13.63 \%$ crude protein which is close to the value $14.89 \%$ crude protein reported by Etuk and Ukaejiofor (2007) and higher than 8.8\% and $9.65 \%$ crude protein for maize reported by Olomu (1995) and Abubakar et al. (2006) respectively. The tannin content of the sorghum meal reduced from $0.193 \mathrm{mg} / 100 \mathrm{~g}$ to $0.114 \mathrm{mg} / 100 \mathrm{~g}$ after fermentation. This is in line with the report of sheriff et al. (2012) that water treatment reduced the tannin content of sorghum grain.

Performance of the experimental broiler finisher birds

Data on the performance of the experimental birds are presented in Table 3. There were no significant $(\mathrm{p}>0.05)$ treatment effects on the average daily weight gain, average daily feed intake and feed conversion ratio. $\mathrm{T}_{4}(30 \%)$ inclusion level gave the lowest feed conversion ratio. Feed cost decreased as the inclusion levels of fermented sorghum seed meal increased. It is evident from the result that fermentation enhanced feed consumption and nutrient utilization of the FSSM resulting in better weight gain and feed conversion ratio at $30 \%$ dietary level which happened to have the lowest feed cost.

Table 2: Proximate and tannin composition of Fermented Sorghum Seed Meal (FSSM)

\begin{tabular}{lc}
\hline Parameters & Composition (\%DM) \\
\hline Moisture & 6.75 \\
Crude Protein & 13.63 \\
Crude fibre & 1.27 \\
Ether extract & 1.45 \\
Ash & 1.24 \\
NFE & 75.67 \\
ME (kcal/kg) & 3309.205 \\
Tannin (raw sorghum) $(\mathrm{mg} / 100 \mathrm{~g})$ & 0.193 \\
Tannin (fermented sorghum) $(\mathrm{mg} / 100 \mathrm{~g})$ & 0.114 \\
\hline
\end{tabular}

\section{Carcass characteristics}

Data on the carcass and internal organs of broiler finishers fed fermented sorghum seed meal are presented in Table 4. There were no significant differences $(\mathrm{P}>0.05)$ on all the parameters measured. It all implies that fermented sorghum seed meal had no deleterious effect on any of the organs and therefore did not negatively affect their growth. Therefore, FSSM is good for the healthy growth of the birds. 


\section{Esiegwu}

Table 3: Performance of experimental broiler finisher birds fed graded levels of fermented sorghum seed meal (FSSM)

\begin{tabular}{lrrrrr}
\hline Parameters & $\mathbf{T}_{\mathbf{1}} \mathbf{( 0 \% )}$ & $\mathbf{T}_{\mathbf{2}} \mathbf{( 1 0 \% )}$ & $\mathbf{T}_{\mathbf{3}} \mathbf{( 2 0 \% )}$ & $\mathbf{T}_{\mathbf{4}} \mathbf{( 3 0 \% )}$ & $\mathbf{S E M}$ \\
\hline $\begin{array}{l}\text { Initial body weight } \\
\text { gain (g/bird) }\end{array}$ & 521.33 & 520.00 & 520.67 & 514.67 & 3.786 \\
$\begin{array}{l}\text { Final body weight } \\
\text { gain (g/bird) }\end{array}$ & 1341.67 & 1460.00 & 1543.33 & 1570.00 & 83.487 \\
$\begin{array}{l}\text { Total weight gain } \\
\text { (g/bird) }\end{array}$ & 820.33 & 940.00 & 1022.66 & 1055.33 & 82.111 \\
$\begin{array}{l}\text { Average daily weight } \\
\text { gain (g/bird) }\end{array}$ & 29.29 & 33.57 & 36.52 & 37.02 & 3.005 \\
$\begin{array}{l}\text { Average daily feed } \\
\text { intake (g/bird) }\end{array}$ & 130.19 & 130.95 & 142.91 & 146.02 & 4.712 \\
$\begin{array}{l}\text { Feed conversion ratio } \\
\text { Feed cost per kg ( })\end{array}$ & 4.65 & 3.91 & 4.00 & 3.84 & 0.418 \\
$\begin{array}{l}\text { Feed cost/kg weight } \\
\text { gain ( })\end{array}$ & 112.43 & 104.93 & 97.43 & 89.33 & \\
\hline
\end{tabular}

Table 4: Carcass and internal organ characteristics of broiler finisher birds fed fermented sorghum seed meal (FSSM)

\begin{tabular}{lrrrrr}
\hline Parameters & $\mathbf{T}_{\mathbf{1}} \mathbf{( 0 \% )}$ & $\mathbf{T}_{\mathbf{2}} \mathbf{( 1 0 \% )}$ & $\mathbf{T}_{\mathbf{3}} \mathbf{( 2 0} \% \mathbf{)}$ & $\mathbf{T}_{\mathbf{4}} \mathbf{( 3 0} \% \mathbf{)}$ & SEM \\
\hline Live weight (g/bird) & 1533.33 & 1733.33 & 1833.33 & 1766.67 & 159.826 \\
$\begin{array}{l}\text { Dressed weight } \\
\text { (\%LW) }\end{array}$ & 63.93 & 63.11 & 61.01 & 60.44 & 6.978 \\
Thigh muscle (\%LW) & 21.25 & 19.66 & 20.43 & 18.10 & 1.188 \\
Breast muscle & 16.58 & 15.25 & 18.71 & 15.34 & 1.581 \\
(\%LW) & 18.68 & 18.75 & 19.41 & 13.64 & 1.311 \\
Wings muscle & 7.54 & 8.22 & 9.19 & 8.20 & 0.717 \\
(\%LW) & 2.70 & 3.00 & 3.52 & 2.67 & 0.832 \\
Back muscle (\%LW) & 8.00 & 8.33 & 9.13 & 9.27 & 0.512 \\
Neck muscle (\%LW) & 0.66 & 0.58 & 0.44 & 0.60 & 0.093 \\
Shank muscle & 2.77 & 2.59 & 2.63 & 1.96 & 1.636 \\
Heart muscle (\%LW) & 4.05 & 2.48 & 2.30 & 2.77 & 0.817 \\
Gizzard muscle & 216.33 & 223.00 & 191.67 & 193.33 & 12.826 \\
(\%LW) & & & &
\end{tabular}

Haematological and serum biochemical indices

Data on the haematological and serum biochemical indices of broiler finishers fed fermented sorghum seed meal are presented in Tables 5 and 6 .

The results showed that the haemoglobin (HB), the packed cell volume (PCV) and the red blood cell (RBC) were affected by treatments $(p<0.05)$, increasing as the dietary inclusion of fermented sorghum seed meal increased. Low values of $\mathrm{Hb}$ and $\mathrm{RBC}$ were a good sign of emerging anaemia (Mohammed and Oloyede, 2009) and could be a pointer to congenital heart disease, lung disease, dehydration and kidney disease 


\section{Effect of fermented sorghum seed meal on broiler finisher chicken}

(Odoemelam et al., 2014). The high values for haemoglobin, red blood cell and packed cell volume implies a normal physiological functioning of the blood. The value for haemoglobin was within the normal range (11.60-13.68) (Wikivet, 2013). A decrease in packed cell volume was an indication of liver and kidney disease (Demoranville and Best, 2013). The values of packed cell volume obtained from this study were higher than the values (21.25-30.45) reported by Aguihe, et al. (2014) and within the normal range $(35.9-41.0 \%)$ (Merck, 2012 and Wikivet, 2013). The result showed that there was no negative or toxic effect of the feed on the blood of the animals. The white blood cell, neutrophil, basophil, eosinophil, lymphocytes and monocytes did not show any significant treatment $(\mathrm{p}>0.05)$ effect. The values were within the normal range (4.07-4.84) (Heath and Olusanya, 1985 and Latimer et al., 2003). White blood cell normally rises in the course of infection or invasion by a foreign body in order to resist it. Non significant effect of the values means that there was no infection of the blood.

The biochemical values showed that the feed did not interfere with protein metabolism in the blood, negatively. There were no treatment effect $(p>0.05)$ in the serum protein, albumin and globulin. A decrease in serum protein concentration could be due to an interference of normal protein metabolism (Bolu and Balogun, 2009). The urea content of the blood ranged from $6.00 \mathrm{mmol} / 1$ to $7.47 \mathrm{mmol} / 1$ for $\mathrm{T}_{0}(0 \%)$ to $\mathrm{T}_{4}(30 \%)$ level respectively. It increased significantly at $20 \%$ and $30 \%$ dietary levels which were an indication of a reduction in the protein quality of the blood (Nworgu et al., 2007). The higher the urea level, the lower the protein quality. The values obtained in this study were lower than the values (9.9711.07; $15.00-26.00 \mathrm{mg} / \mathrm{dl})$ reported by Odetola et al. (2015) and Ukpabi et al. (2015) respectively but higher than the values $(2.68$ - $3.97 \mathrm{mmol} / \mathrm{l}$ ) obtained by Ashom et al. (2016). The cholesterol content of the blood increased significantly as the dietary inclusion of fermented sorghum seed meal increased. Similar observation was reported by Ukpabi et al. (2015) for finisher broilers fed raw Adenanthera pavonina seed meal and Nworgu et al. (2007) for broilers fed fluted pumpkin leaf extract supplement.

Table 5: Haematological indices of broiler finisher birds fed fermented sorghum seed meal (FSSM)

\begin{tabular}{|c|c|c|c|c|c|}
\hline Parameters & $T_{1}(0 \%)$ & $T_{2}(10 \%)$ & $T_{3}(20 \%)$ & $\mathrm{T}_{4}(30 \%)$ & SEM \\
\hline $\mathrm{HB}(\mathrm{g} / \mathrm{dl})$ & $12.13^{\mathrm{b}}$ & $12.57^{\mathrm{ab}}$ & $12.97^{\mathrm{a}}$ & $13.20^{\mathrm{a}}$ & 0.218 \\
\hline $\operatorname{PCV}(\%)$ & $36.67^{\mathrm{c}}$ & $38.67^{\mathrm{bc}}$ & $41.67^{\mathrm{ab}}$ & $42.67^{\mathrm{a}}$ & 1.054 \\
\hline $\mathrm{WBC}\left(\mathrm{X} 10^{9} / \mathrm{L}\right)$ & 11.33 & 11.27 & 11.60 & 11.60 & 0.258 \\
\hline $\mathrm{RBC}\left(\mathrm{X} 10^{12} / \mathrm{L}\right)$ & $11.67^{\mathrm{b}}$ & $12.20^{\mathrm{ab}}$ & $12.77^{\mathrm{a}}$ & $13.13^{\mathrm{a}}$ & 0.299 \\
\hline $\operatorname{ESR}\left(\mathrm{mm} / 15^{+} / \mathrm{hr}\right)$ & $46.67^{b}$ & $41.67^{\mathrm{ab}}$ & $33.33^{\mathrm{ab}}$ & $30.00^{\mathrm{b}}$ & 4.330 \\
\hline $\mathrm{MCV}(\mathrm{FL})$ & 31.70 & 31.00 & 32.40 & 32.53 & 0.715 \\
\hline $\mathrm{MCH}(\mathrm{PS})$ & 10.40 & 10.30 & 10.03 & 10.10 & 0.217 \\
\hline $\mathrm{MCHC}(\mathrm{g} / \mathrm{dl})$ & $33.10^{\mathrm{a}}$ & $32.53^{\mathrm{ab}}$ & $31.17^{\mathrm{ab}}$ & $30.97^{b}$ & 0.597 \\
\hline Neutrophiles (\%) & 53.33 & 53.33 & 52.67 & 55.33 & 1.054 \\
\hline Basophiles (\%) & Nil & Nil & Nil & Nil & Nil \\
\hline Eosinophiles (\%) & 1.67 & 1.67 & 1.67 & 1.33 & 0.334 \\
\hline Lymphocytes (\%) & 44.33 & 44.33 & 44.33 & 41.33 & 0.882 \\
\hline Monocytes (\%) & 1.67 & 1.67 & 1.33 & 2.00 & 0.289 \\
\hline
\end{tabular}




\section{Esiegwu}

Table 6: Serum biochemical indices of broiler finisher birds fed fermented sorghum seed meal (FSS)

\begin{tabular}{|c|c|c|c|c|c|}
\hline \multirow[b]{2}{*}{ Parameters } & \multicolumn{4}{|c|}{ Dietary Levels of FSSM (\% DM) } & \multirow[b]{2}{*}{ SEM } \\
\hline & $T_{1}(0 \%)$ & $T_{2}(10 \%)$ & $T_{3}(20 \%)$ & $\mathrm{T}_{4}(\mathbf{3 0} \%)$ & \\
\hline Urea $(\mathrm{mmol} / \mathrm{L})$ & $6.00^{\mathrm{b}}$ & $6.43^{\mathrm{b}}$ & $7.23^{\mathrm{a}}$ & $7.47^{\mathrm{a}}$ & 0.187 \\
\hline Creatinine $(\mathrm{mmol} / \mathrm{L})$ & 57.00 & 66.00 & 54.00 & 59.67 & 5.372 \\
\hline $\begin{array}{l}\text { Cholesterol } \\
(\mathrm{mmol} / \mathrm{L})\end{array}$ & $7.27^{\mathrm{b}}$ & $7.43^{\mathrm{b}}$ & $8.07^{\mathrm{a}}$ & $8.47^{\mathrm{a}}$ & 0.149 \\
\hline Total Protein $(\mathrm{g} / \mathrm{dl})$ & 59.33 & 60.67 & 65.00 & 65.00 & 1.972 \\
\hline Albumin (g/dl) & 23.67 & 20.00 & 23.00 & 23.33 & 1.795 \\
\hline Globulin (g/dl) & 32.33 & 40.67 & 42.33 & 43.67 & 1.041 \\
\hline Sodium $(\mathrm{mmol} / \mathrm{L})$ & 42.00 & 41.33 & 42.33 & 43.67 & 1.041 \\
\hline Potassium $(\mathrm{mmol} / \mathrm{L})$ & 1.20 & 1.23 & 1.23 & 1.47 & 0.170 \\
\hline $\begin{array}{l}\text { Bicarbonate } \\
(\mathrm{mmol} / \mathrm{L})\end{array}$ & 10.37 & 10.77 & 11.00 & 11.00 & 0.208 \\
\hline Chlorine (mmol/L) & 21.67 & 23.33 & 21.67 & 24.67 & 1.236 \\
\hline Alkaline phosphate & 1.13 & 1.30 & 1.27 & 1.40 & 0.080 \\
\hline SGOT & $11.07^{\mathrm{b}}$ & $11.30^{\mathrm{b}}$ & $12.20^{\mathrm{a}}$ & $12.43^{\mathrm{a}}$ & 0.137 \\
\hline SGPT & $6.47^{b}$ & $6.50^{\mathrm{b}}$ & $7.03^{\mathrm{ab}}$ & $7.53^{\mathrm{a}}$ & 0.180 \\
\hline
\end{tabular}

High cholesterol level at $20 \%$ and $30 \%$ dietary level may stimulate hypercholesterolemia. The enzymes serum glutamate oxaloacetate transaminase (SGOT) and serum glutamate pyruvate transaminase (SGPT) increased significantly at $20 \%$ and $30 \%$ dietary levels. This is a sign that at this level the organs and protein quality may be challenged by the presence of anti nutrients. The enzymes were used to check the toxicity of feed to the organs and monitor protein quality.

\section{Conclusion}

The study revealed that fermented sorghum seed meal had no negative effect on performance indices such as weight gain and feed intake even at 30\% dietary level. The feed did not show any damaging or negative effect on the carcass value.

There was no sign of infection or toxic influence on the blood by the feed apart from the protein quality that indicated sign of reduction at $20 \%$ and $30 \%$ dietary levels. The trial also revealed that fermented sorghum seed meal was very cost effective even at $30 \%$ dietary level

\section{References}

Abubakar, M., Doma, U. D., Kalla, D. J. U., Ngele, M. B. and Augustine, C. L. D. 2006. Effects of dietary replacement of maize with malted and unmalted sorghum on performance of weaner rabbits. Livest. Res. Rur. Dev. 18(5).

Accuweather.2015. Weather for Owerri, $\begin{array}{llllllll}\mathbf{N} & \mathbf{i} & \mathbf{g} & \mathbf{e} & \mathbf{r} & \mathbf{i} & \mathbf{a} & \text {. }\end{array}$ http://www.accuweather.com/en/ng lowerri/ $253317 /$ weatherforecast $/ 253317$. Retrieved on November 15, 2015.

Aguihe, P. C., Kehinde, A. S., Fatokun, B. O., Omotugba, S. K. and Ashifat, A. A. 2014. Effect of enzyme supplementation on haematology and serum biochemistry of broiler finishers fed cassava peel meal based diets. Trop. Anim. Prod. Invest. 17(1): 47-51.

AOAC 2010. Association of official analytical chemists.Official methods of analysis, $19^{\text {th }}$ edition. 


\section{Effect of fermented sorghum seed meal on broiler finisher chicken}

Washington D.C.

Ashom, S. A., Tuleun, C. D. and Carew, S. N. 2016. Serum biochemical indices of finisher broiler chickens fed diets containing unprocessed and variously processed Roselle (Hibiscus sabdariffa L.) seeds. Nigerian J. Anim. Sci. 2: 356-363.

Bolu, S. A. and Balogun, O. O. 2009. Effects of improved (addition of anti microbials and anti oxidants ) locally produced natural vitamin premix on performance, haematology and some serum constituents of broiler chickens. Nig. J. Anim. Prod. 36(2): $246-$ 255.

Demoranville, V. E. and Best, M. A. 2013. Haematocrit.Encyclopedia of Surgery.A guide for patients and caregivers. Available at: e $n$ w i k i p e d i a. Org/Wiki/Haematology.

Dicko, M. H., Gruppen, H., Traore, A. S, Van Berkel, W. J. H. and Voragen, A. G. L. 2005. Evaluation of the effect of germination on content of phenolic compound and antioxidant activities in sorghum varieties. $J$. Agric. Food Chem.53, 2581 2588.

Doka, O., Bicanic, D. D., Dicko, M. H, and Slingerland, M. A. 2004. Photo acaustic approach to direct determination of the totalphenolic content in red sorghum flours. $J$. Agric. Food chem. 52, 2133 2136.

Dowling, L. F., Amdt, C. and Hamaker, B. R. 2002. Economic viability of high digestibility sorghum as feed for market broiler. Agron. J. 94:1050-1058.

Etuk, E. B., and Ukaejiofo, U. R. 2007.
Tannin content and dietary effect of brown coat coloured sorghum on the performance of young local turkey. Anim. Prod. Res. Adv. 3(2): 86-90.

Heath, E. and Olusanya, S. 1985. Anatomy and Physiology of Tropical Livestock. Longman group U.K PP.31.

Jain, N. C. 1986. Schaulm Veterinary Haematology. $4^{\text {th }}$ ed., Philadelphia, Lea and Febiger.

Kim, H. S. and Miller, D. D. 2005. Prolinerich proteins moderate the inhibitory effect of tea on iron absorpton in rats. J. Nutr. $135,532-$ 537.

Latimer, K. S., Mahaffey, E. A. and Prasse, K. W. 2003. Duncan and Prasse Veterinary Laboratory Medicine.Clinical Pathology, $4^{\text {th }}$ ed. Willey Blackwell

Merck Manual 2012. Haematologic reference ranges. Merck Veterinary manua l. Retrieved from http://www.merckmanuals.com/.

Mohammed, N. O. and Oloyede, O. B. 2009. Growth performance of broiler chicks fed Aspergillusnigerfermented Terminaliacatappa seed meal based diets. Global journal of biotechnology and biochemistry 4(2): $179-183$.

Monica, C. 1984. Medical laboratory manual for tropical countries vol 11.Microbiology ELBS Edn.

Nworgu, F. C., Ogungbenro, S. A. and Solesi, K. S. 2007. Performance and some blood chemistry indices of broiler chickens served fluted pumpkin (Telfariaoccidentalis) leaves extract supplement. American Euraisan Journal of Agric. and Environ.Science. 2(1): 90-98.

Obi, I. U. 1990. Statistical methods of 


\section{Esiegwu}

detecting differences between means $2^{\text {nd }} E d n$, snap press. Enugu , Nigeria.

Ochie, J. and Kolhatkar, A. 2000. Medic al laboratory science.Theory and practice. Tata McGraw-Hill company limited New Delhi.

Odetola, O. M., Eruvbetine, D., Adejinmi, O. O. and Akapo, 0 . A . 2015 . $\quad$ G $\mathrm{r}$ o $\mathrm{w} \mathrm{t} \mathrm{h}$ response, haematology, serum biochemistry and carcass characteristics of broilers fed graded levels of raw kenaf (Hibiscus canna-binus) seed meal as a replacement for soya bean meal. Nig. J. Anim. Sci. 17(2): 199206

Odoemelam, V. U., Ndelekwute, E. K., Igbonaeme, U. J. and Ogbuewe, I. P. 2014. Comparative effect of Basil leaf (Ocimumgratissimum) meal and antibiotic growth promoter (oxytetracyclineHcl) on haematology and biochemical indices of broiler chickens. Nigerian Journal of Animal science. 16(2): 235-243.
Olomu. J. M. 1995. Monogastric Animal Nutrition - Principles and Practice. A Jachem Publication, Benin City, Nigeria, PP. $112-118$

Pauzenga, U. 1985. Feeding parent stock zootechnica international. PP. 22 25

Sharif, M., Idreas, M., Tauqir, N. A., Shahzad, M. A., Khalif, M. F., Nisa, M., Sarwa, M. and Khan, $M$. L. 2012. Effect of water treatment of sorghum on the performance of broiler chicks. South African Journal of Animal Science.42 (No.2)

Snedecor, G. W. and Cochran, W. G. 1978. Statistical Methods.The IOWA State University Press, Ames - Iowa $6^{\text {th }}$ edn.

Ukpabi, U. H., Mbachu, C. I. and Nwazue, B. 2015. Effect of inclusion of different levels of rawAdenantherapavonina seed meal (RAPSM) on haemathology andblood biochemistry of finisher broiler. Nig.J.Anim. Sci. 17 (1): 28 36.

Wikivet. 2013. Haematology: Available at en.wikipedia/wiki/haematology.

Received: $11^{\text {th }}$ February, 2017

Accepted: $21^{\text {st }}$ June, 2017 